\title{
Pengaruh Inovasi Produk dan Harga Terhadap Keputusan Pembelian Sepeda Motor Honda di Kota Bekasi
}

\author{
Dani Chandra Utama \\ Universitas Bina Sarana Informatika \\ dani.dcu@bsi.ac.id
}

\begin{abstract}
This study aimed to analyze the impact of innovation and price on purchase decisions. The research was carried out at different places to get a full range of respondents. The sample was the owner of the vehicle Honda motorcycle in Bekasi totaling 150 respondents. Regression analysis techniques were used to analyze the impact of innovation and price of the purchasing decision is by using SPSS (Statistical Package for the Social Sciences). The analysis showed that the product innovation and significant positive effect on purchasing decisions, each increase of one unit in the variable product innovation will be followed by an increase of 0.401 unit purchasing decisions. The analysis also showed that prices positive and significant influence on purchasing decisions, any adjustment of the unit either affordability of the price, the suitability of the price of the product quality, price competitiveness, and suitability prices with benefits will influence the purchase decision of Honda motorcycles for 0538 unit. This shows that the innovation products made by Honda and Prices set affects $46.6 \%$ of the consumer decision in purchasing undergo a Honda motorcycle in Bekasi.
\end{abstract}

Keywords : Innovation, Price, Purchase Decision, Motorcycles, Honda.

\section{PENDAHULUAN}

Penerapan strategi pemasaran yang tepat diharapkan akan meningkatkan volume penjualan sehingga dapat memenangkan persaingan. Setiap perusahaan pada umumnya ingin berhasil dalam menjalankan usahausahanya. Usaha-usaha untuk mencapai tujuan yang telah ditetapkan perusahaan adalah salah satunya melalui kegiatan pemasaran.

Kebutuhan alat transportasi sepeda motor di Indonesia dari tahun ketahun semakin meningkat. Hal ini merupakan peluang besar bagi perusahaan industri otomotif roda dua atau sepeda motor untuk menawarkan produknya guna meningkatkan angka penjualan dengan berbagai cara. Dalam pemasaran produknya banyak industri yang menerapkan strategi, diantaranya yaitu strategi kualitas, inovasi produk dan harga.

Pentingnya memahami keinginan konsumen dalam produk yang dibutuhkannya telah menjadi perhatian pada berbagai industri, termasuk pada industri otomotif. Saat ini perkembangan teknologi dunia otomotif sangat cepat, khususnya sepeda motor. Produksi sepeda motor kini bukan lagi hanya di tujukan untuk memenuhi kebutuhan utama bagi masyarakat guna kepentingan mobilisasi, namun juga berkembang kearah gaya hidup. Berbagai jenis bentuk (design), aksesoris dan kapasitas mesin sepeda motor dikembangkan guna menarik minat konsumen.

Banyak bermunculannya industri otomotif baru sepeda motor, memaksa perusahaan lama seperti Honda, untuk dapat terus melakukan inovasi guna mempertahankan eksistensinya di tengah iklim persaingan global. Banjirnya produk otomotif roda dua asal negeri China dan India menambah ketatnya persaingan guna memenangkan hati konsumen. Meningkatkan serta mempertahankan kualitas produk masih dianggap cara jitu bagi perusahaan untuk dapat menaikkan nilai produk di mata konsumen, di mana hal tersebut akan sangat berdampak pada keputusan pembelian.

Selain itu ada hal lain yang juga berpengaruh terhadap keputusan pembelian, yaitu inovasi terhadap produk dan kebijakan harga. Inovasi terhadap produk dianggap dapat menghilangkan rasa jenuh atau kebosanan konsumen terhadap pilihan produk yang cenderung kurang beragam serta tidak memiliki keunikan. Sedangkan kebijakan harga atau penentuan harga yang tepat pada setiap produk sangat berpengaruh terhadap proses pertimbangan konsumen dalam mengambil keputusan untuk melakukan pembelian.

Keputusan pembelian merupakan suatu proses pengambilan keputusan akan pembelian yang mencakup penentuan apa yang akan dibeli atau tidak melakukan pembelian dan keputusan itu diperoleh dari kegiatan-kegiatan sebelumnya (Assauri, 2004). Sedangkan keputusan pembelian adalah pengambilan keputusan oleh konsumen untuk melakukan pembelian suatu produk diawali oleh adanya kesadaran atas pemenuhan kebutuhan dan keinginan yang oleh Assael disebut need arousal (Sutisna, 2002).

Keputusan pembelian konsumen merupakan keputusan pembelian konsumen akhir perorangan dan rumah tangga yang membeli barang dan jasa untuk konsumsi pribadi (Philip Kotler, 2009), sedangkan menurut Kotler dan Armstrong, keputusan pembelian adalah membeli merek yang paling 
disukai, tetapi dua faktor bisa berada antara niat pembelian dan keputusan pembelian. Faktor pertama adalah sikap orang lain. Faktor kedua adalah faktor situasional yang tidak diharapkan (Philip Kotler \& Armstrong, 2012).

Pada saat konsumen membeli sebuah produk umumnya konsumen mengikuti suatu proses atau tahapan dalam pengambilan keputusan. Menurut ( $\mathrm{P}$ Kotler, 2008), terdapat 5 tahapan proses pembelian, yakni:

1. Pengenalan kebutuhan

adalah tahapan pertama proses keputusan pembeli, dimana konsumen menyadari suatu masalah atau kebutuhan.

2. Pencarian informasi

adalah tahap proses keputusan pembeli, dimana konsumen ingin mencari informasi lebih banyak, konsumen mungkin hanya memperbesar perhatian atau melakukan pencarian informasi secara aktif.

3. Evaluasi alternatif

adalah tahap proses keputusan pembeli, dimana konsumen menggunakan informasi untuk mengevaluasi merek alternatif dlam sekelompok pilihan.

4. Keputusan pembelian keputusan pembeli tentang merek mana yang di beli.

5. Perilaku pasca pembelian

Tahap proses keputusan pembelian dimana konsumen mengambil tindakan selanjutnya setelah pembelian, berdasarkan kepuasan mereka atau ketidakpuasan mereka.

Tjiptono menjelaskan inovasi produk bisa diartikan sebagai implementasi praktis sebuah gagasan ke dalam produk atau proses baru. Inovasi bisa bersumber dari individu, perusahaan, riset di universitas, laboratorium (Tjiptono \& Gregorius, 2008). Selain itu inovasi (Innovation) dapat diartikan sebagai pengembangan dan perbaikan praktis dari suatu penemuan (invention) awal menjadi teknik yang dapat dipakai (inovasi proses) atau produk (inovasi produk) (Pass \& Lowes, 1994).

Selanjutnya menurut Kotler, inovasi produk merupakan setiap barang, jasa, atau gagasan yang dianggap sebagai sesuatu yang baru (Philip Kotler, 2007). Sedangkan pengertian inovasi produk menurut Solomon dan Stuart dalam Uliana menyatakan produk baru atau inovasi dalam konteks pemasaran adalah barang, jasa maupun ide yang dipersepsikan sebagai sesuatu yang baru dan berbeda dari barang, jasa maupun ide yang telah ada sebelumnya (Uliana, 2012).

Rogers menyatakan bahwa inovasi terdiri atas lima dimensi (Rogers, 2003), antara lain sebagai berikut: 1. Keunggulan relatif (relative advantage),
Adalah tingkat kelebihan suatu inovasi, apakah lebih baik dari inovasi yang ada sebelumnya atau dari hal-hal yang biasa dilakukan. Biasanya diukur dari segi ekonomi, prestasi sosial, kenyamanan dan kepuasan. Semakin besar keuntungan relatif yang dirasakan oleh adopter, maka semakin cepat inovasi tersebut diadopsi.

2. Kesesuaian / keserasian (compatibility)

Adalah tingkat kesesuaian inovasi dengan nilai (values), pengalaman lalu, dan kebutuhan dari penerima. Inovasi yang tidak sesuai dengan nilai atau norma yang diyakini oleh penerima tidak akan diterima secepat inovasi yang sesuai dengan norma yang ada.

3. Kerumitan (complexity)

Adalah tingkat kerumitan dari suatu inovasi untuk diadopsi, seberapa sulit memahami dan menggunakan inovasi. Semakin mudah suatu inovasi dimengerti dan dipahami oleh adopter, maka semakin cepat inovasi diadopsi. Sebaliknya Semakin komplek produk bersangkutan, semakin sulit produk itu memperoleh penerimaan.

4. Ketercobaan (trialability)

Merupakan tingkat apakah suatu inovasi dapat dicoba terlebih dahulu atau harus terikat untuk menggunakannya. Suatu inovasi dapat diujicobakan pada keadaan sesungguhnya, inovasi pada umumnya lebih cepat diadopsi. Untuk lebih mempercepat proses adopsi, maka suatu inovasi harus mampu menunjukkan keunggulannya. Produk baru lebih mungkin berhasil jika konsumen dapat mencoba atau bereksperimen dengan ide secara terbatas.

5. Keterlihatan (observability)

Tingkat bagaimana hasil penggunaan suatu inovasi dapat dilihat oleh orang lain. Semakin mudah seseorang melihat hasil suatu inovasi, semakin besar kemungkinan inovasi diadopsi oleh orang atau sekelompok orang. Keterlihatan dan kemudahan komunikasi mencerminkan tingkat di mana hasil dari pemakaian produk baru terlihat oleh teman dan tetangga.

Pengertian harga menurut Peter dan Olson adalah kondisi dimana konsumen harus menyerahkan sesuatu untuk membeli produk atau jasa (Peter \& Olson, 2000). Sedangkan menurut Lamarto harga adalah jumlah nilai (kemungkinan ditambah beberapa barang) yang dibutuhkan untuk memperoleh beberapa kombinasi sebuah produk dan pelayanan yang menyertainya (Lamarto, 1996).

Selanjutnya pengertian harga menurut Kotler dalam Simamora harga adalah nilai yang dipertukarkan konsumen untuk suatu manfaat atas pengkonsumsian, penggunaan atau kepemilikan barang atau jasa (Simamora, 2003). Sedangkan harga menurut Swastha adalah sejumlah uang yang dibutuhkan untuk mendapatkan sejumlah kombinasi dari barang serta pelayanan (Swastha, 1984). 
Ada 4 hal yang mencirikan harga menurut pendapat (Stanton, 1998) yaitu:

1. Keterjangkauan harga

Artinya konsumen bisa menjangkau harga yang telah ditetapkan oleh perusahaan. Produk biasanya ada beberapa jenis dalam satu merek, dan harganya juga berbeda dari termurah sampai termahal.

2. Kesesuaian harga dengan kualitas produk Harga sering dijadikan sebagai indikator kualitas bagi konsumen. Orang sering memilih harga yang lebih tinggi diantara dua barang karena melihat adanya perbedaan kualitas. Apabila harga lebih tinggi orang cenderung beranggapan bahwa kualitasnya juga lebih baik

3. Daya saing harga

Konsumen sering membandingkan harga suatu produk dengan produk lainnya. Mahal murahnya harga suatu produk sangat dipertimbangkan oleh konsumen pada saat akan membeli suatu produk.

4. Kesesuaian harga dengan manfaat

Semakin tinggi manfaat yang dirasakan oleh konsumen dari barang atau jasa tertentu, semakin tinggi pula nilai tukar barang atau jasa tersebut, semakin besar pula alat penukar yang tersedia yang dikorbankan konsumen.

\section{METODE PENELITIAN}

\subsection{Tempat dan Waktu Penelitian}

Penelitian dilaksanakan di beberapa dealer yang juga sekaligus bengkel motor Honda yang berada di wilayah kawasan Bekasi. Sedangkan obyek penelitiannya adalah para pemilik sepeda motor Honda yang berdomisili di wilayah Kota Bekasi. Pelaksanaan penelitian dijadwalkan selama empat bulan, yaitu mulai bulan April 2016 s/d bulan Juli 2016.

\subsection{Populasi dan Sampel Penelitian}

Menurut Sugiyono populasi adalah seluruh individu yang menjadi objek penelitian, sedangkan sampel adalah sampel adalah bagian dari jumlah dan karakteristik yang dimiliki oleh populasi tersebut (Sugiyono, 2011). Dalam penelitian ini populasinya adalah para pemilik sepeda motor Honda yang berdomisili di wilayah Bekasi, sedangkan sampel dalam penelitian ini diambil dengan metode teknik pengambilan sampel Random Sampling, yaitu teknik penentuan sampel secara acak dan semua sampel memperoleh peluang yang sama. Jumlah sampel ditetapkan sebesar 150 orang dengan pertimbangan bahwa jumlah populasi memiliki jumlah yang sangat besar, pengambilan sampel sesuai dengan pendapat (Hair Jr., Black, Babin, \& Anderson, 1998) bahwa untuk mendapatkan analisis statistik yang baik, jumlah sampel harus memenuhi sebanyak 4 sampai dengan 10 kali jumlah indikator kuesioner yang ditetapkan.

\subsection{Sumber Data}

Data yang digunakan dalam penelitian ini adalah data primer, yaitu data yang diperoleh langsung dari penyebaran kuesioner di lokasi penelitian. Peneliti menggunakan kuesioner yang dibagikan kepada responden secara langsungkepada siswa yang menjadi sampel dalam penelitian ini.

\subsection{Metode Analisis}

Untuk penelitian ini peneliti menggunakan analisis regresi berganda dengan alat bantu software SPSS 20.00. Adapun persamaan regresi berganda dalam penelitian ini adalah:

$$
\widehat{\boldsymbol{Y}}=a+b_{1} X_{1}+b_{2} X_{2}+e
$$

Di mana:

$\widehat{\mathbf{Y}}=$ Estimasi rata-rata Kep Pembelian

a = Konstanta dari persamaan regresi.

$\mathrm{b}_{1}=$ Intercep variabel $\mathrm{X}_{1}$ (Inovasi Produk)

$\mathrm{X}_{1}=$ Skor variabel $\mathrm{X}_{1}$

$\mathrm{b}_{2}=$ Intercep variabel $\mathrm{X}_{2}$ (Harga)

$\mathrm{X}_{2}=$ Skor variabel $\mathrm{X}_{2}$

e $=$ Error atau sisa (residual).

Pengujian signifikansi regresi bivariat (regresi sederhana) antara variabel independen terhadap

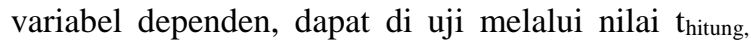
sedangkan pengujian signifikansi regresi berganda dengan menggunakan nilai $\mathrm{F}_{\text {hitung, }}$

\section{HASIL DAN PEMBAHASAN}

3.1. Karakteristik Responden

Hasil penelitian dengan menyebar kuesioner kepada 150 responden di beberapa dealer yang juga sekaligus bengkel motor Honda yang berada di wilayah kawasan Bekasi, berdasarkan pendapat Fraenkel dan Wallen, besar sampel minimum untuk penelitian deskriptif sebanyak 100 sampel, sedangkan penelitian ini menggunakan 150 sampel sehingga penelitian sudah melebihi syarat yang ditentukan (Fraenkel \& Wallen, 1993).

Responden dalam penelitian lebih didominasi oleh pria yakni sebesar 74,67 persen, sedangkan responden dengan jenis kelamin wanita hanya sebesar 25,33 persen. Usia responden dominan berusia diantara 46-50 tahun yakni sebesar 19,30 persen, kemudian 41-45 tahun yakni sebesar 18,70 persen, dan diantara 31-35 tahun sebesar 18 persen. Pekerjaan sebagian besar berstatus sebagai karyawan swasta yakni sebesar 31,33 persen, responden yang berprofesi sebagai wiraswasta sebesar 28 persen, responden yang berprofesi buruh sebesar 14,67 persen.

\subsection{Uji Validitas dan Reliabilitas}


Hasil uji validitas dan reliabilitas pada item kuesioner penelitian yang diuji pada 30 responden awal dapat dilihat pada tabel berikut:

\begin{tabular}{|c|c|c|c|c|}
\hline $\begin{array}{c}\text { Variab } \\
\text { el }\end{array}$ & Item Pertanyaan & $\begin{array}{c}\mathbf{r} \\
\text { hitun } \\
\mathbf{g}\end{array}$ & $\begin{array}{c}r \\
\text { tabe } \\
l\end{array}$ & Ket \\
\hline \multirow{20}{*}{$\begin{array}{l}\text { Inovasi } \\
\text { Produk }\end{array}$} & & $0,652^{*}$ & 0,36 & Val \\
\hline & Inovasi Produk 1 & & 1 & id \\
\hline & & $0,770^{*}$ & 0,36 & Val \\
\hline & Inovasi Produk 2 & * & 1 & id \\
\hline & & $0,693^{*}$ & 0,36 & Val \\
\hline & Inovasi Produk 3 & * & 1 & id \\
\hline & & $0,809^{*}$ & 0,36 & Val \\
\hline & Inovasi Produk 4 & $*$ & 1 & $\mathrm{id}$ \\
\hline & & $0,766^{*}$ & 0,36 & Val \\
\hline & Inovasi Produk 5 & * & 1 & id \\
\hline & & $0,819^{*}$ & 0,36 & Val \\
\hline & Inovasi Produk 6 & * & 1 & id \\
\hline & & $0,860^{*}$ & 0,36 & Val \\
\hline & Inovasi Produk 7 & * & 1 & id \\
\hline & & $0,895^{*}$ & 0,36 & Val \\
\hline & Inovasi Produk 8 & & 1 & id \\
\hline & & $0,825^{*}$ & 0,36 & Val \\
\hline & Inovasi Produk 9 & $*$ & 1 & id \\
\hline & & $0,626^{*}$ & 0,36 & Val \\
\hline & Inovasi Produk 10 & & 1 & id \\
\hline $\begin{array}{c}\text { Variab } \\
\text { el }\end{array}$ & Item Pertanyaan & $\begin{array}{c}\mathbf{r} \\
\text { hitun } \\
\mathbf{g}\end{array}$ & $\begin{array}{c}r \\
\text { tabe } \\
l\end{array}$ & Ket \\
\hline \multirow{16}{*}{ Harga } & & $0,733^{*}$ & 0,36 & Val \\
\hline & Harga 1 & * & 1 & id \\
\hline & & $0,652^{*}$ & 0,36 & Val \\
\hline & Harga 2 & * & 1 & id \\
\hline & & $0,764^{*}$ & 0,36 & Val \\
\hline & Harga 3 & & 1 & id \\
\hline & & $0,837^{*}$ & 0,36 & Val \\
\hline & Harga 4 & * & 1 & id \\
\hline & & $0,820^{*}$ & 0,36 & Val \\
\hline & Harga 5 & * & 1 & id \\
\hline & & $0,568^{*}$ & 0,36 & Val \\
\hline & Harga 6 & * & 1 & id \\
\hline & & $0,606^{*}$ & 0,36 & Val \\
\hline & Harga 7 & $*$ & 1 & id \\
\hline & & $0,611^{*}$ & 0,36 & Val \\
\hline & Harga 8 & & 1 & id \\
\hline $\begin{array}{c}\text { Variab } \\
\text { el }\end{array}$ & Item Pertanyaan & $\begin{array}{c}\mathbf{r} \\
\text { hitun } \\
\mathbf{g}\end{array}$ & $\begin{array}{c}r \\
\text { tabe } \\
l\end{array}$ & Ket \\
\hline \multirow{16}{*}{$\begin{array}{c}\text { Keputu } \\
\text { san } \\
\text { Pembel } \\
\text { ian }\end{array}$} & Keputusan & $0,636^{*}$ & 0,36 & Val \\
\hline & Pembelian 1 & & 1 & id \\
\hline & Keputusan & $0,636^{*}$ & 0,36 & Val \\
\hline & Pembelian 2 & $*$ & 1 & id \\
\hline & Keputusan & $0,771^{*}$ & 0,36 & Val \\
\hline & Pembelian 3 & & 1 & id \\
\hline & Keputusan & $0,806^{*}$ & 0,36 & Val \\
\hline & Pembelian 4 & & 1 & id \\
\hline & Keputusan & $0,710^{*}$ & 0,36 & Val \\
\hline & Pembelian 5 & & 1 & id \\
\hline & Keputusan & $0,692^{*}$ & 0,36 & Val \\
\hline & Pembelian 6 & & 1 & id \\
\hline & Keputusan & $0,821^{*}$ & 0,36 & Val \\
\hline & Pembelian 7 & & 1 & id \\
\hline & Keputusan & $0,800^{*}$ & 0,36 & Val \\
\hline & Pembelian 8 & * & 1 & id \\
\hline
\end{tabular}

\begin{tabular}{lrccc}
\hline Keputusan & $0,565^{*}$ & 0,36 & Val \\
Pembelian 9 & ${ }^{*}$ & 1 & id \\
\cline { 2 - 5 } Keputusan & $0,600^{*}$ & 0,36 & Val \\
Pembelian 10 & ${ }^{*}$ & 1 & id \\
\hline Keputusan & $0,755^{*}$ & 0,36 & Val \\
Pembelian 11 & ${ }^{*}$ & 1 & id \\
\hline Keputusan & $0,796^{*}$ & 0,36 & Val \\
Pembelian 12 & ${ }^{*}$ & 1 & id \\
\hline
\end{tabular}

Sumber: Hasil Penelitian (2019)

Berdasarkan hasil pengolahan data pada tabel diatas, item pertanyaan pada setiap variabel semuanya valid, sebab nilai $r$ hitung lebih besar dari nilai $r$ tabel $(r$ hitung > r tabel).

Tabel 2. Uji Reliabilitas

\begin{tabular}{clccc}
\hline No & Variabel & $\begin{array}{c}\text { Cronbach } \\
\text { Alpha }\end{array}$ & Standar & Ket \\
\hline 1 & $\begin{array}{l}\text { Inovasi } \\
\text { Produk }\end{array}$ & 0,922 & 0.600 & Reliabel \\
\hline 2 & Harga & 0,852 & 0.600 & Reliabel \\
\hline 3 & $\begin{array}{l}\text { Keputusan } \\
\text { Pembelian }\end{array}$ & 0,907 & 0.600 & Reliabel \\
\hline
\end{tabular}

Sumber: Hasil Penelitian (2019)

Berdasarkan hasil pengolahan data, semua variabel dalam penelitian ini valid, hal itu dapat dilihat dari nilai cronbach alpha pada semua variabel lebih besar dari nilai standar.

\subsection{Uji Asumsi Klasik}

a. Uji Normalitas Data

Uji normalitas berguna untuk menentukan data Menurut Ghozali, uji normalitas bertujuan untuk menguji apakah dalam model regresi, variabel pengganggu atau residual memiliki distribusi normal, bila asumsi ini dilanggar maka uji statistik menjadi tidak valid untuk jumlah sampel kecil (Ghozali, 2011). Model regresi yang baik adalah distribusi mendekati normal. Uji ini dilakukan dengan bantuan program Statistical Package for Social Science (SPSS) dengan menggunakan metode normal probability plot (NPP).

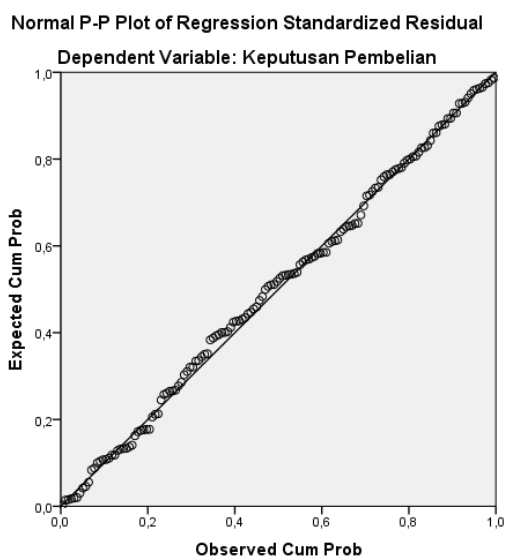

Sumber: Hasil Penelitian (2019)

Gambar 1. Grafik Uji Normalitas 
Dari Gambar 1 dapat dilihat bahwa adanya titik-titik yang menyebar dan disekitar garis diagonal serta penyebarannyapun mengikuti arah garis diagonal. Hal tersebut membuktikan bahwa model regresinya telah memenuhi asumsi normalitas.

\section{b. Uji Homogenitas}

Menurut Sugiyono uji homogenitas varian bertujuan untuk menentukan apakah varian kedua kelompok homogen atau tidak (Sugiyono, 2011). Dalam analisis regresi berganda untuk mendapatkan hasil yang baik varians dalam komponen pengganggunya harus sama (homokedastisitas). Jika asumsi ini tidak bisa dipenuhi maka data adalah homogen.

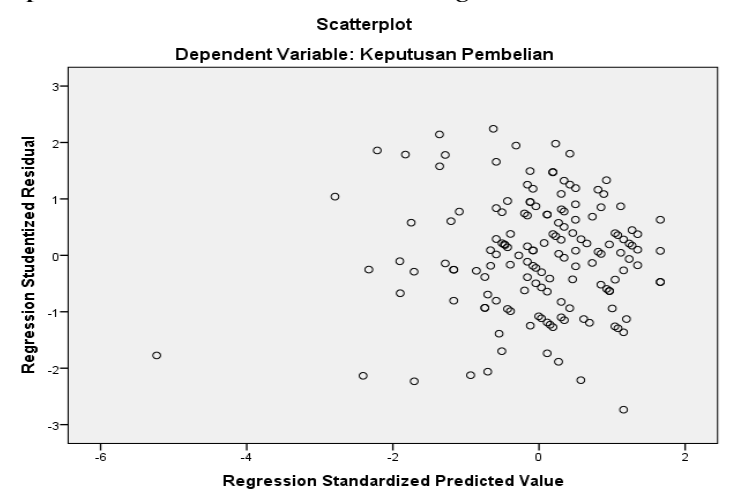

Sumber: Hasil Penelitian (2019)

Gambar 2. Grafik Uji Homogenitas

Dari Gambar 2 terlihat bahwa titik-titik menyebar secara acak tidak membentuk pola tertentu yang jelas, seperti bergelombang, melebar kemudian menyempit. Selain itu titik-titik tersebut menyebar diatas dan dibawah angka pada sumbu Y, maka dapat disimpulkan bahwa data adalah homogen.

\section{c. Uji Multikolinieritas}

Tujuan uji asumsi multikolinearitas adalah untuk menguji apakah model regresi ditemukan adanya korelasi antar variabel independen. Untuk mendeteksi ada tidaknya gejala multikolinearitas maka dilakukan dengan melihat Variance Inflation Factor (VIF), bila nila VIF lebih kecil dari 10 maka tidak terjadi multikolinieritas.

Tabel 4. Uji Multikolinieritas

\begin{tabular}{ccl}
\hline Variabel & VIF & Keterangan \\
\hline $\mathrm{X}_{1}$ & 1,465 & Non Multikolinieritas \\
\hline $\mathrm{X}_{2}$ & 1,465 & Non Multikolinieritas \\
\hline
\end{tabular}

Sumber: Hasil Penelitian (2019)

Berdasarkan Tabel 4 diketahui bahwa diantara variabel-variabel bebas yang digunakan mempunyai nilai VIF lebih kecil dari 10, dari hasil tersebut dapat disimpulkan bahwa model regresi linier tersebut bebas dari multikolinearitas atau tidak terjadi korelasi diantara satu dengan yang lain.

\subsection{Pengujian Hipotesis}

\section{a. Pengujian Hipotesis $\mathbf{t}(\mathrm{Ujj}$ t $)$}

Pengujian hipotesis ini untuk mengetahui apakah variabel independen berpengaruh sendiri-sendiri terhadap variabel terikat dan variabel independen (bebas) manakah yang paling dominan pengaruhnya terhadap Keputusan Pembelian. Dari hasil Uji t dari tabel 5 menujukkan bahwa terdapat 2 variabel independen (X) mempunyai pengaruh yang signifikan terhadap variabel dependen (Y). Secara rinci dapat dijelaskan sebagai berikut :

1) Inovasi Produk $\left(X_{1}\right)$

Untuk variabel Inovasi Produk $\left(\mathrm{X}_{1}\right)$ memiliki nilai signifikansi 0,000 . Nilai Sig $\mathrm{t}<5 \%$ $(0,000<0,05)$. Dengan demikian pengujian Ho ditolak dan Ha diterima. Hal ini memperlihatkan bahwa Inovasi Produk $\left(\mathrm{X}_{1}\right)$ berpengaruh positif dan signifikan terhadap Keputusan Pembelian (Y). Adapun besarnya pengaruh adalah sebesar 0,401 .

2) Harga $\left(X_{2}\right)$

Untuk variabel Harga $\left(\mathrm{X}_{2}\right)$ memiliki nilai signifikansi 0,000 . Nilai Sig $\mathrm{t}<5 \%(0,00 .<$ $0,05)$. Dengan demikian pengujian Ho ditolak dan Ha diterima. Hal ini memperlihatkan bahwa Harga $\left(\mathrm{X}_{2}\right)$ berpengaruh positif dan signifikan terhadap Keputusan Pembelian (Y). Adapun besarnya pengaruh adalah sebesar 0,538 .

Jadi, kesimpulan yang dapat diambil berdasarkan pengujian hipotesis diatas adalah variabel Inovasi Produk dan Harga berpengaruh secara parsial terhadap Keputusan Pembelian. dan yang mempunyai pengaruh paling dominan adalah Harga.

\section{b. Pengujian Hipotesis F (Uji F)}

Pengujian hipotesis ini yaitu untuk mengetahui pengaruh antara seluruh variabel independen (bebas) dengan variabel dependen (terikat). Dalam hipotesis penelitian ini, diduga bahwa seluruh variabel Inovasi Produk $\left(\mathrm{X}_{1}\right)$ dan variabel Harga $\left(\mathrm{X}_{2}\right)$ secara serempak mempengaruhi Keputusan Pembelian. Hasil pengujian hipotesis $\mathrm{F}$ dapat dilihat pada tabel berikut: Tabel 6. Hasil Uji F (Anova)

\begin{tabular}{|c|c|c|c|c|c|c|}
\hline \multirow{2}{*}{\multicolumn{2}{|c|}{ Model }} & \multicolumn{3}{|c|}{ ANOVA $^{\mathrm{a}}$} & \multirow[b]{2}{*}{$\mathrm{F}$} & \multirow[b]{2}{*}{ Sig. } \\
\hline & & Sum of & $\mathrm{df}$ & Mean & & \\
\hline \multirow{3}{*}{1} & $\begin{array}{l}\text { Regressio } \\
n\end{array}$ & 1784,336 & 2 & 892,168 & $\begin{array}{r}66, \\
087\end{array}$ &, $000^{\mathrm{b}}$ \\
\hline & Residual & 1984,497 & 147 & 13,500 & & \\
\hline & Total & 3768,833 & 149 & & & \\
\hline
\end{tabular}

a. Dependent Variable: Keputusan Pembelian

b. Predictors: (Constant), Harga, Inovasi Produk

Sumber: Hasil Penelitian (2019)

Berdasarkan hasil perhitungan yang dapat dilihat pada tabel 4.11, menunjukkan Signifikansi $F=0.000$. Jadi Sig F $<5 \%(0.000<0.05)$, dengan demikian $\mathrm{Ha}$ diterima dan Ho ditolak yang berarti bahwa secara serempak variabel $\mathrm{X}_{1}, \mathrm{X}_{2}$ mempunyai pengaruh yang signifikan terhadap variabel Y. Jadi terbukti bahwa 
variabel Inovasi Produk $\left(\mathrm{X}_{1}\right)$ dan variabel Harga $\left(\mathrm{X}_{2}\right)$ berpengaruh secara bersama-sama terhadap Keputusan Pembelian.

\section{KESIMPULAN}

Kesimpulan yang dapat diberikan dalam penelitian ini adalah:

1. Inopvasi Produk yang dilakukan pleh produsen Honda sudah baik, namun untuk memenangi persaingan dengan merk motor lainnya, manajemen Honda perlu meningkatkan inovasi produk secara terus menerus dan melakukan riset yang mendalam tentang keinginan konsumen di Indonesia.

2. Manajemen Honda perlu mencari cara dalam mempertahankan dan meraih penjualan yang tinggi, dengan merealisasikan program-program promosi yang membuat harga yang ditetapkan menjadi layak untuk dipertimbangkan calon konsumen sepeda motor dalam rangka memilih dan memutuskan pembelian jenis sepeda motor ditengah persaingan dengan merk lain yang semakin sengit.

3. Hasil penelitian menunjukkan bahwa inovasi produk dan harga mempengaruhi keputusan pembelian konsumen sebesar 46,6 persen, yang berarti terdapat 53,4 persen variabel yang tidak diteliti. Untuk penelitian mendatang disarankan agar mengikutsertakan variabel-variabel lain yang diduga berpengaruh terhadap keputusan pembelian sepeda motor Honda, seperti kualitas pelayanan dan layanan purna jual.

4. Penelitian mendatang diharapkan dilakukan didaerah selain Bekasi dengan menggunakan sampel dari berbagai latar belakang dan tingkat usia serta area yang lebih luas untuk memverifikasi hasil penelitian ini.

5. Dengan demikian, berdasarkan hasil penelitian, untuk meningkatkan keputusan pembelian yang pada akhirnya akan meningkatkan penjualan sepeda motor Honda, manajemen Honda Motor perlu meningkatkan inovasi produk yang lebih baik dan menetapkan harga sesuai dengan daya beli masyarakat.

\section{REFERENSI}

Assauri, S. (2004). Manajemen Pemasaran. Jakarta: PT. Raja Grafindo Persada.
Fraenkel, J. R., \& Wallen, N. E. (1993). How to Design and Evalute Researche in Education. New York: Mc Graw-Hill Inc.

Ghozali, I. (2011). Aplikasi Analisis Multivariate Dengan Program IBM SPSS 19 (Edisi Keli). Semarang: Universitas Diponegoro.

Hair Jr., J. F., Black, W. C., Babin, B. J., \& Anderson, R. E. (1998). Multivariate Data Analysis (Fifth Edit). New Jersey: Pearson.

Kotler, P. (2007). Manajemen Pemasaran (Edisi Kedu). Jakarta: PT. Indeks.

Kotler, P. (2008). Manajemen Pemasaran (Edisi Mile). Jakarta: PT. Prehallindo.

Kotler, P. (2009). Manajemen Pemasaran (Jilid 9). Jakarta: PT. Prehallindo.

Kotler, P., \& Armstrong, G. (2012). Prinsip-prinsip Pemasaran (Edisi 13). jakarta: Erlangga.

Lamarto, Y. (1996). Prinsip Pemasaran (Edisi Ketu). Jakarta: Erlangga.

Pass, C., \& Lowes, B. (1994). Kamus Lengkap Ekonomi (Edisi Kedu). Jakarta: Erlangga.

Peter, J. P., \& Olson, J. C. (2000). Consumer Behavior: Perilaku Konsumen dan Strategi Pemasaran (Edisi Keem). Jakarta: Erlangga.

Rogers, M. E. (2003). Diffusion of Innovation (Fifth Edit). New York: Free Press.

Simamora, B. (2003). Membongkar Kotak Hitam Konsumen. Jakarta: PT. Gramedia Pustaka Utama.

Stanton, W. J. (1998). Prinsip Pemasaran (Edisi Ketu). Jakarta: Erlangga.

Sugiyono. (2011). Metode Penelitian Kuantitatif Kualitatif dan $R \& D$. Bandung: Alfabeta.

Sutisna. (2002). Perilaku Konsumen. Bandung: Rosda Karya.

Swastha, B. (1984). Azas-azas Marketing (Edisi Keti). Yogyakarta: Liberty.

Tjiptono, F., \& Gregorius, C. (2008). Service, Quality and Satisfaction (Edisi Kedu). Yogyakarta: CV. Andi.

Uliana, D. (2012). Pengaruh Inovasi Produk Terhadap Purchase Intention (Studi Pada Starbucks Via). University of Indonesia.

\section{Biodata Penulis}

Dani Chandra Utama, SE, MM. Tahun 2001 lulus dari Program Strata Satu (S1) Universitas Gunadarma. Tahun 2016 lulus dari Program Strata Dua (S2) Program Studi Magister Ilmu Manajemen Universitas BSI. Aktif menjadi dosen di Universitas Bina Sarana Informatika sejak tahun 2010. 